\title{
Gender and Age Differences in Attitudes of Serbian Pupils toward Physical Education Lessons and their Preferences Regarding Lesson Organisation
}

\author{
Bojan Mašanović
}

University of Montenegro, Faculty for Sport and Physical Education

\section{Abstract}

This research has been conducted with the aim of evaluating gender and age differences in attitudes of Serbian students toward Physical Education lessons and their preferences regarding lesson organisation. The sample of 542 students was divided into 4 subsamples: 140 female primary school pupils (13.51 \pm 0.41$)$

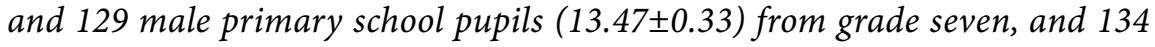

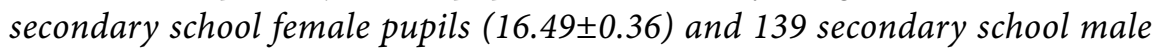
pupils (16.44 \pm 0.37$)$ from grade two. For the purpose of the research, the subjects voluntarily filled in two standardised questionnaires. ANOVA was used to determine significant differences in attitudes toward Physical Education lessons between pupils of different age and of different gender, while a Chi-square test was used to determine significant differences in pupils' preferences regarding Physical Education lesson organisation. The results showed that primary school pupils had significantly more positive attitudes toward Physical Education lessons in relation to secondary school pupils, and that younger pupils prefer gender-based organisation of lessons which changes with respect to age and gender.

Key words: lessons; primary and secondary schools; Serbia.

\section{Introduction}

Lately, a growing number of researchers has been investigating questions on pupils' attitudes toward teaching and their preferences regarding the organisation of teaching (Atan \& Imamoglu, 2016; Mercier, Donovan, Gibbone, \& Rozga, 2017; 
Silverman \& Subramaniam, 1999; Trudeau \& Shephard, 2005; Yaman, 2007; Yildizer, Ozboke, Tascioglu, \& Yilmaz, 2017). Namely, the researchers are interested in questions regarding the insufficient number of Physical Education lessons per week, quality of teaching, teaching contents and methods, and properly equipped space for Physical Education lessons or diversity of props used for teaching, as well as in questions related to the frequency of adolescents' avoidance of lessons (Babin, Bavčević, Vlahović, 2013; Babin, Bavčević, \& Prskalo, 2010; Bavčević, 2016; Bavčević, Babin, \& Prskalo, 2006; Morgan \& Hansen, 2008; Olafson, 2002).

A significant number of available studies indicate that the determining factors of gender and age influence pupils' attitudes toward Physical Education lessons and their preferences regarding the organisation of teaching in these lessons (Lyu \& Gill, 2011; Shropshire, Carroll, \& Yim, 1997; Subramaniam \& Silverman, 2007). Accordingly, a great number of researchers have studied attitudes of both boys and girls of different age with the aim of proving the presence of necessity to modernise the curricula or design different activities within the existing ones in order to satisfy the needs, primarily of girls and boys, but also of children of different age. Boys and girls have a tendency to participate in different sports (Alm \& Brolin Laftman, 2018; Slater \& Tiggemann, 2011), so girls usually choose sports with an aesthetic component while boys prefer sports that are dominated by physical contact and strength (Wellard, 2017). Girls are more likely to choose sports that do not endanger stereotypes of female behaviour and appearance, such as volleyball, skating or similar, while boys prefer high risk sports such as, primarily combat sports, rugby, hockey or other related activities (Clément-Guillotin, Chalabaev, \& Fontayne, 2012). Although there are significant differences such as physiological, anatomical, psychological and socio-cultural between the genders (Greydanaus \& Patel, 2002), by looking into the past, it is easily observed that sport was traditionally the area reserved for men's achievements, boys participated in Physical Education lessons while girls were at the same time trained elsewhere to be good housekeepers (Coakley, 2015). However, in the last decades of the previous century and into present day, the tendency regarding physical activities is to neutralise differences between the genders (Klomsten, Skaalvik, \& Espnes, 2004). Even though sports are equally available, the fact is that today, girls participate less frequently in sporting activities than boys (Schmalz \& Kerstetter, 2006), which continues to be a problem with which a significant number of researchers are concerned.

It is widely known that during the adolescent years, characteristic biological changes and significant differences in the interests of both boys and girls change with regard to their surroundings. Accordingly, when Physical Education is in question, it is interesting to emphasise that girls' interest in Physical Education lessons significantly decreases (Sarkin, McKenzie, \& Sallis, 1997) while many studies concluded that boys' interest in Physical Education lessons remains at the same level as in the preadolescent years (Vilhjalmsson \& Kristjansdottir, 2003). The previously mentioned is influenced by a generally accepted cultural model of a man, which is reflected in his 
role as a defender and family breadwinner, therefore boys are more sports oriented, since it can be a potential source of financial gain or personal value (Ryska, 2003). Still, it is a fact that both boys and girls treat sports differently (Alić, 2017), and encouragement for participation in physical activities also differs from one society to another, conditioned by the traditional stereotypes (Eagly \& Wood, 1999) and specificities of certain societies, so any research such as this one is conditioned to a great extent by the social and cultural specificities (Wilson, 2002).

On the other hand, when we refer to the age difference, it is interesting to point out that pupils' motivation for participating in physical activities in the adolescent years follows the process of growing up (Marttinen, Fredrick, \& Silverman, 2018). Namely, the reasons for negative attitudes of older pupils toward Physical Education lessons can be observed in the diversity of interests among older children offered by modern life and less and less space for physical activity (Mehmeti, 2015). For example, there is a growing number of gamers representing children's idols, while adolescents identifying with athletes is not frequently seen these days (Sindik, Rendulić, Čorak, \& Lewis, 2014). Also, a significant factor which has a negative impact is parents' influence, which weakens as children grow up, indicated by deviation of children from healthy lifestyles (Boisa, Sarrazina, Brustad, Trouilloud, \& Cury, 2005; Cote, 1999).

When referring to the organisation of teaching, conclusions found in the literature indicate that there are no differences in attitudes with respect to gender among pupils, when we talk about preferences regarding the organization of the lesson (Arabaci, 2009). However, the fact is that there are differences between subjects of different age, where primary school pupils prefer teaching in homogeneous groups, or groups where boys and girls are physically separated (Lyu \& Gill, 2011), while secondary school pupils prefer organisation of teaching in mixed groups (Koca, Asci, \& Demirhan, 2005).

Research on gender and age differences in attitudes of Serbian pupils toward Physical Education lessons and their preferences regarding the organisation of teaching is limited, that is, there is no study which could adequately answer the research question which came from the previously listed facts and both regional and cultural specificities. Because of that, this study might provide insight into specific knowledge lading to improvement of the current condition of this culturally specific country. The aim of this study was to test attitudes of Serbian pupils toward Physical Education lessons in relation to gender and age.

\section{Method}

\section{Subjects and Sample Characteristics}

This research included a sample of 542 primary and secondary school pupils from Bačka Topola and Srbobran (North Bačka and South Bačka Districts of the Autonomous Province of Vojvodina, i.e., the Northern part of the Republic of Serbia), divided into 4 subgroups: 140 female primary school pupils (average age $=13.51$; $\mathrm{SD}= \pm 0.41$ ) and 129 male primary school pupils (average age $=13.47 ; \mathrm{SD}= \pm 0.33$ ) 
from grade seven, and 134 female secondary school pupils (average age $=16.49 ; \mathrm{SD}=$ \pm 0.36 ) and 139 male secondary school pupils (average age $=16.44 ; \mathrm{SD}= \pm 0.37$ ) from grade two. Primary school seventh graders and secondary school second graders had been chosen based on differences regarding biological development, psychological maturity and age specific interests, while teaching was implemented in all classes in conformity with the curriculum of the Republic of Serbia, which provides two 45-minute lessons per week. Content of other European countries and content of the Serbian curriculum differ at the practical levels, since primary activities are sports games, track-and-field and gymnastics. Criteria for the selection of subjects for the sample were as follows: regular attendance in Physical Education lessons and place of residence on the territory of the Republic of Serbia.

\section{Instruments}

The research technique used for establishing pupils' attitudes toward Physical Education lessons and their preferences regarding the lesson organisation in relation to the gender and age was a survey which included two questionnaires. The first questionnaire consisted of two parts. The first part included questions on address, age, school results and gender, while the second part included questions on the lesson organisation preferred by pupils: teaching in mixed or in homogeneous groups (Arabaci, 2009). The second questionnaire was a standardised questionnaire titled "Attitude Toward Physical Education Scale" (Demirhan \& Altay, 2001).

\section{Measurement Procedure}

Filling out the questionnaires took about 10 minutes, and subjects voluntarily decided to participate in the research. Since they were all underage, a written consent from their parents was obtained. It is important to emphasise that the survey was anonymous and that all answers were strictly confidential. Subjects, besides the mentioned, were given the possibility to withdraw from the survey at any moment, but no one decided to do so. Data collection was implemented in their schools during Homeroom Class.

\section{Data Analysis}

The obtained data were analysed using the Statistical Package for Social Sciences (SPSS for Windows, version 20.0). ANOVA was used for determining significant differences in attitudes toward Physical Education lessons between pupils of different age, while Chi-square test was used for investigating significant differences in preferences toward Physical Education lessons. The level of statistical significance was set at $\mathrm{p}<0.05$.

\section{Results}

Table 1 shows descriptive statistics parameters for attitudes of primary and secondary school pupils toward Physical Education lessons. Table 1 shows significant 
difference in attitudes toward Physical Education lessons between female and male pupils from primary and secondary school $(\mathrm{F}=31.419, \mathrm{p}<0.05)$. Average values of the results obtained from the "Attitude Toward Physical Education Scale" show higher values for primary school pupils (3.96), unlike secondary school pupils who had lower results (3.58).

If we analyse only participants from secondary school, there is a significant difference between the genders $(\mathrm{F}=29.351, \mathrm{p}<0.01)$, in favour of boys of this age group (3.76) in relation to girls (3.42). A similar situation is found for the results of only primary school pupils $(\mathrm{F}=2.211)$. The difference based on gender is also significant $\mathrm{p}<0.05$, and the values of results obtained with the use of the "Attitude Toward Physical Education Scale" among pupils are again in favour of boys (4.00) in relation to girls (3.96). Finally, Table 1 clearly shows that attitudes toward Physical Education lessons change with respect to age both for boys $(\mathrm{F}=26.252 ; \mathrm{p}<0.05)$ and girls $(\mathrm{F}=33.759$; $\mathrm{p}<0.05)$. Higher values are noticed among primary school pupils (4.00), in relation to secondary school pupils (3.76), and also the values of results on the evaluation scale are higher for primary school female pupils (3.96) in relation to secondary school female pupils (3.42).

\begin{tabular}{|c|c|c|c|}
\hline Group & $\mathrm{N}$ & Mean & SD \\
\hline \multicolumn{4}{|c|}{ Primary school } \\
\hline Girls & 140 & 3.96 & 0.58 \\
\hline Boys & 129 & 4.00 & 0.56 \\
\hline Total & 269 & 3.98 & 0.57 \\
\hline \multicolumn{4}{|c|}{ Secondary school } \\
\hline Girls & 134 & 3.42 & 0.60 \\
\hline Boys & 139 & 3.76 & 0.64 \\
\hline Total & 273 & 3.59 & 0.62 \\
\hline
\end{tabular}

Table 2 shows descriptive statistics parameters for primary and secondary school pupils' preferences regarding the organisation of Physical Education lessons. Preferences of pupils of different age differ significantly $\left(E^{2}=62.649, p<0.05\right)$. Primary school pupils prefer teaching organised in homogeneous groups (66.54\%), unlike the majority of secondary school pupils (68.86\%), who prefer teaching organised in mixed groups.

No statistically significant difference was found for inclination toward a certain type of Physical Education lessons organisation between subjects of each gender, neither among primary school pupils $\left(E^{2}=.290 ; \mathrm{p}>0.05\right)$ nor secondary school pupils $\left(E^{2}=1.179, p>0.05\right)$. The majority of primary school pupils are more inclined toward lessons organised in homogeneous groups, valid for $67.85 \%$ of girls and $65.12 \%$ for boys. On the contrary, the majority of secondary school pupils, $67.13 \%$ for girls and $70.50 \%$ for boys, are more inclined toward lessons organised in mixed groups. 
If we make a comparison between female pupils of different age in relation to their preferences regarding the organization of Physical Education lessons, we can see that there is a significant difference $\left(E^{2}=25.791 ; \mathrm{p}<0.05\right)$, and that significant difference is also found between boys of different age $\left(E^{2}=30.697 ; \mathrm{p}<0.05\right)$.

Table 2

Serbian primary and secondary school pupils' preferences regarding Physical Education lessons

\begin{tabular}{lcccc}
\hline & \multicolumn{2}{c}{ Mixed groups } & \multicolumn{2}{c}{ Homogenous groups } \\
\hline Group & $\mathrm{N}$ & $\%$ & $\mathrm{~N}$ & $\%$ \\
\hline Primary school & & & & \\
Girls & 45 & 32.15 & 95 & 67.85 \\
Boys & 45 & 34.88 & 284 & 65.12 \\
Total & 90 & 33.46 & 179 & 66.54 \\
Secondary school & & & & \\
Girls & 90 & 67.16 & 44 & 32.84 \\
Boys & 98 & 70.50 & 41 & 29.50 \\
Total & 188 & 68.86 & 85 & 31.14 \\
\hline
\end{tabular}

\section{Discussion and Conclusion}

The results of this research show that there are significant differences in attitudes toward Physical Education lessons between different age groups. Primary school seventh graders have statistically significantly more positive attitudes toward Physical Education lessons in relation to secondary school second graders. These results are in agreement with previous studies (Atan \& Imamoglu, 2016; Silverman \& Subramaniam, 1999; Subramaniam \& Silverman, 2007), which also report a more positive relationship of pupils from the first level of primary school toward Physical Education lessons in relation to pupils from the second level of primary school. The reason for the loss of interest among secondary level pupils for Physical Education lessons is their maturity, which comes with multiple commitments and more responsibility, but also with insufficient democracy in class, which provides pupils with only traditional activities such as sporting games, track-and-field, and gymnastics (Bjelica \& Petković, 2009).

On the other hand, the differences noticed between members of each gender group regarding attitudes toward Physical Education lessons are not surprising. More positive attitudes in both age groups were found among boys, which is, of course, in agreement with the reports in literature (Shropshire et al., 1997; Subramaniam \& Silverman, 2007; Trudeau \& Shepard, 2005). One of the reasons for negative attitudes among girls lies in the fact that the curriculum provides mostly team sports, with only certain elements from track-and-field and gymnastics. Such curriculum content is less interesting to girls in relation to sports which demand aesthetic elements and which are not included as much as girls would prefer (Koivula, 2001). Girls like being on their own, they frequently turn to individual sports (Clément-Guillotin et al., 2012; Schmalz \& 
Kerstetter, 2006), which is not provided by the current curriculum. Contrary to this, boys' desire to stand out, be popular among boys like them and with members of the opposite gender, is well known. Physical activity offers them, through an overall fitness progress, and also through success achieved at school competitions, the possibility to prove themselves as well as to identify themselves with successful athletes or other idols they are trying to imitate or follow (Zivanovic, Pavlovic, Randjelovic, Pirsl, \& Zivkovic, 2015).

It is important not to forget the data that primary school female pupils have more positive attitudes toward Physical Education lessons than secondary school female pupils. This is also an expected result and it is in agreement with the earlier reports which indicate that girls, until they turn thirteen, are equally if not more interested in sports activities in relation to boys, but after this period, the situation changes (Van Wersch, Trew, \& Turner, 1992). An important motive for women to take up sports is fighting for equality, and the desire to show that they are not the weaker sex as a given (Gromeier, Koester, \& Schack, 2017). This motive is frequently present in the period of late childhood and early adolescent years, when competing with friends gives a special motive to emphasise one's own competence (Frederics \& Eccles, 2002; Gibbons, Lynn, \& Stiles, 1997). However, at that point, when the overall teaching load becomes heavier for pupils, girls prefer to neglect sports activities and to concentrate on tasks traditionally related to the female gender (Coakley, 2015), and they are also inclined to adopt, earlier than boys, adult-like behaviour and interests, that is they are more worried with everyday adult issues (Singh, Dhanda, \& Shanwal, 2010).

The other thing the results of this research show is that preference toward Physical Education lesson organisation significantly changes during the period of maturation, therefore, significant differences are noticed between primary school and secondary school pupils. Primary school pupils are more likely to prefer teaching in homogeneous groups (66.54\%), unlike secondary school pupils who prefer lessons organised in gender mixed groups (68.86\%). A reason for different preferences can be seen in changes of attitudes toward the other gender, which consequently indicates better gender tolerance among older girls and boys (Arabaci, 2009). If we compare this data with previous studies, we will find great similarities between them, so Koca, Asci, and Demirhan (2005) indicate the fact that the majority of pupils from the second level of primary school prefer lessons organised in gender mixed groups, while Lyu and Gill (2011) claim that pupils in the first level of primary school prefer lessons organised in gender homogeneous groups. As far as preferences regarding Physical Education lesson organisation are concerned among subjects of different genders, no statistical differences were found for female or male pupils of both primary and secondary school.

In order for teaching to be interesting to secondary school pupils and girls of both ages, who show less interest in Physical Education lessons in Serbian schools, it is necessary to modernise the existing curriculum. It is crucial to break the solid 
barriers and resistance preventing positive changes because the aim of teaching is for children to be active and happy. Department for Education Improvement, that is, the Centre for Programmes and Textbooks Development, which carries out professional activities related to the preparation of curriculum, must attentively follow results of the studies related to interests of the school population, and prepare materials in order to satisfy demands of the contemporary society. Physical Education lessons should not only be an opportunity to learn, exercise and compete, emphasis should rather be on friendship and kindness (Bjelica \& Petković, 2009), which is also one of the demands which need to be met. This study can help in achieving that goal.

The reason for implementing the research in Backka Topola and Srbobran, towns situated in North Bačka, that is, South Bačka District of the Autonomous Province of Vojvodina, in the Northern part of the Republic of Serbia, is that generalisation of the obtained data is not referred to the entire territory of Serbia, as it would threaten the external research validity. The Autonomous Province of Vojvodina differs from other areas, above all due to the multi-ethnic population including more than 25 ethnic communities living in this territory, which may influence specific attitudes of pupils toward Physical Education lessons and their preferences toward the organisation of those lessons. This area is culturally isolated due to its high exposure to the influence of developed Western countries, as a part of Austria-Hungary until 1918. We must also take into consideration its economy based on wealth of highly arable land which provided the population with a different lifestyle in relation to the population of the other Serbian districts. Therefore, it is reasonable to expect, though we are not certain due to lack of research of this type in the Serbian territory, that the complete image of the entire country might be different, so it is necessary to expand the research to other regions in order to investigate potential differences. In agreement with this, future studies should be implemented on a larger sample including pupils from all parts of Serbia, i.e. pupils from all 29 administrative districts. This way, it would be possible to exclude differences in attitudes and preferences which might occur due to ethnical, religious, financial and language differences of people who live in harmony on the territory of Serbia. This kind of approach would surely contribute to the quality of the results, but it would not reduce the contribution of this preliminary study. What is more, it would provide more representative data based on which specific steps could be taken to modify the existing curricula.

\section{References}

Alić, J. (2017). Gender Differences in Goal Orientation between High School Students in Physical Education Classes. Croatian Journal of Education, 19(Sp.Ed.No.2), 171-188. https:// doi.org/10.15516/cje.v19i0.2691

Alm, S., \& Brolin Laftman, S. (2018). The Gendered Mirror on the Wall: Satisfaction with Physical Appearance and Its Relationship to Global Self-esteem and Psychosomatic 
Complaints Among Adolescent Boys and Girls. Young, 26(5),525-541. https://doi. org/10.1177/1103308817739733

Arabaci, R. (2009). Attitudes toward physical education and class preferences of Turkish secondary and high school students. Elementary Education Online, 8(1), 2-8.

Atan, T., \& Imamoglu, M. (2016). Attitudes of secondary school students towards physical education and sports lesson in terms of various variables. Turkish Journal of Sport and Exercise, 18(2), 65-68. https://doi.org/10.15314/tjse.48459

Babin, B., Bavčević, T., \& Vlahović, L. (2013). Relations of motor abilities and motor skills in 11- year- old pupils. Croatian Journal of Education, 15(2), 251-274.

Babin, J., Bavčević, T., \& Prskalo, I. (2010). Comparative analysis of the specially programmed kinesiological activity on motor area structural changes of male pupils aged 6 to 8 . Odgojne znanosti, 12(1), 79-96.

Bavčević, T. (2016). Interpersonal Communication in Education - Analysis and Systematisation of Research Directions. Croatian Journal of Education, 18(4), 1201-1233. https://doi.org/10.15516/cje.v18i4.1919

Bavčević, T., Babin, J., \& Prskalo, I. (2006). Complex group organizational forms - an optimizing factor in Physical education instruction. Kinesiology, 38(1), 28-39.

Bjelica, D., \& Petković, J. (2009). Teorija fizičkog vaspitanja i osnove školskog sporta. Podgorica: Crnogorska sportska akademija.

Boisa, J. E., Sarrazina, P. G., Brustad, R. J., Trouilloud, D. O., \& Cury, F. (2005). Elementary schoolchildren's perceived competence and physical activity involvement: the influence of parents' role modelling behaviours and perceptions of their child's competence. Psychology of Sport and Exercise, 6(4), 381-397. https://doi.org/10.1016/j.psychsport.2004.03.003

Clément-Guillotin, C., Chalabaev, A., \& Fontayne, P. (2012). Is Sport still a masculine domain? A psychological glance. International Journal of Sport Psychology, 43(1),67-78.

Coakley, J. (2015). Assessing the sociology of sport: On cultural sensibilities and the great sport myth. International Review for the Sociology of Sport, 50(4-5), 402-406.

Coakley, J. (2015). Assessing the sociology of sport: On cultural sensibilities and the great sport myth. International Review for the Sociology of Sport, 50(4-5), 402-406. https://doi.org/10.1177/1012690214538864

Cote, J. (1999). The Influence of the Family in the Development of Talent in Sport. The Sport Psychologist, 13(4), 395-417. https://doi.org/10.1123/tsp.13.4.395

Demirhan, G., \& Altay, F. (2001). Lise Birinci Sinıf Ogrencilerinin Beden Egitimi ve Spor Dersine İliskin Tutum Olcegi II. Hacettepe Universitesi Spor Bilimleri Dergisi, 12(2), 9-20.

Eagly, A. H., \& Wood, W. (1999). The origins of sex differences in human behavior: Evolved dispositions versus social roles. American Psychologist, 54(6), 408-423. https://doi. org/10.1037/0003-066X.54.6.408

Frederics, J. A., \& Eccles, J. S. (2002). Children's competence and value beliefs from childhood through adolescence: Growth trajectories in two male-sex-typed domains. Developmental Psychology, 38(4), 519-533. https://doi.org/10.1037/0012-1649.38.4.519

Gibbons, J. L., Lynn, M., \& Stiles, D. A. (1997). Cross-National Gender Differences in Adolescents' Preferences for Free-Time Activities. Cross-Cultural Research, 31(1), 55-69. https://doi.org/10.1177/106939719703100104 
Greydanus, D. E., \& Patel, D. R. (2002). The female athlete. Before and beyond puberty. Pediatric clinics of North America, 49(3), 553-580. https://doi.org/10.1016/S00313955(02)00005-6

Gromeier, M., Koester, D., \& Schack, T. (2017). Gender Differences in Motor Skills of the Overarm Throw. Frontiers in Psychology, 8(212), 1-12. https://doi.org/10.3389/ fpsyg.2017.00212

Klomsten, A. T., Skaalvik, E. M., \& Espnes, G. A. (2004). Physical Self-Concept and Sports: Do Gender Differences Still Exist? Sex roles, 50(1-2), 119-127. https://doi.org/10.1023/ B:SERS.0000011077.10040.9a

Koca, C., Asci, F. H., \& Demirhan, G. (2005). Attitudes toward physical education and class preferences of Turkish adolescents in terms of school gender composition. Adolescence, 40(158), 365-375.

Koivula, N. (2001). Perceived characteristics of sports categorized as gender-neutral, feminine and masculine. Journal of Sport Behavior, 24(4), 377-393.

Lyu, M., \& Gill, D. L. (2011). Perceived physical competence, enjoyment and effort in same-sex and coeducational physical education classes. Educational Psychology, 31(2), 247-260. https://doi.org/10.1080/01443410.2010.545105

Marttinen, R. N., Fredrick, R., \& Silverman, S. S. (2018). Middle school students' free-living physical activity on physical education days, non-physical education days, and weekends. Montenegrin Journal of Sports Science and Medicine, 7(1), 5-12. https://doi.org/10.26773/ missm.180301

Mehmeti, I. (2015). Motivational level and participation barriers in school physical education among adolescents. Sport Mont, 13(43-44-45), 121-126.

Mercier, K., Donovan, C., Gibbone, A., \& Rozga, K. (2017). Three-Year Study of Students' Attitudes Toward Physical Education: Grades 4-8. Research quarterly for exercise and sport, 88(3), 307-315. https://doi.org/10.1080/02701367.2017.1339862

Morgan, P., \& Hansen, V. (2008). Teachers' Perceptions of the Impact of Barriers to Teaching Physical Education on the Quality of Physical Education Programs. Research Quarterly for Exercise and Sport, 79(4), 506-516. https://doi.org/10.1080/02701367.2008.10599517

Olafson, L. (2002). "I hate phys. ed.": Adolescent girls talk about physical education. Physical Educator, 67-74.

Ryska, T. A. (2003). Sportsmanship in Young Athletes: The Role of Competitiveness, Motivational Orientation, and Perceived Purposes of Sport. The Journal of Psychology Interdisciplinary and Applied, 137(3), 273-293. https://doi.org/10.1080/00223980309600614

Sarkin, J. A., McKenzie, T. L., \& Sallis, J. F. (1997). Gender Differences in Physical Activity during Fifth-Grade Physical Education and Recess Periods. Journal of Teaching in Physical Education, 17(1), 99-106. https://doi.org/10.1123/jtpe.17.1.99

Schmalz, D. L., \& Kerstetter, D. L. (2006). Girlie Girls and Manly Men: Children's Stigma Consciousness of Gender in Sports and Physical Activities. Journal of Leisure Research, 38(4), 536-557. https://doi.org/10.1080/00222216.2006.11950091

Shropshire, J., Carroll, B., \& Yim, S. (1997). Primary School Children's Attitudes to Physical Education: Gender Differences. European Journal of Physical Education, 2(1), 23-38. https:// doi.org/10.1080/1740898970020103 
Silverman, S., \& Subramaniam, P. R. (1999). Student Attitude Toward Physical Education and Physical Activity: A Review of Measurement Issues and Outcomes. Journal of Teaching in Physical Education, 19(1), 97-125. https://doi.org/10.1123/itpe.19.1.97

Sindik, J., Rendulić, D., Čorak, S., \& Lewis, A. (2014). Analysis of the Relevant Factors of Retaining Women in Judo. Montenegrin Journal of Sports Science and Medicine, 3(2), 23-31.

Singh, C. K., Dhanda, B., \& Shanwal, P. (2010). Gender Difference in Motor and Mental Development in Children: An Impact of Stimulating Activities. The Anthropologist, 12(2), 153-154. https://doi.org/10.1080/09720073.2010.11891146

Slater, A., \& Tiggemann, A. (2011). Gender differences in adolescent sport participation, teasing, self-objectification and body image concerns. Journal of Adolescence, 34(3), 455463. https://doi.org/10.1016/j.adolescence.2010.06.007

Subramaniam, P. R., \& Silverman, S. (2007). Middle school students' attitudes toward physical education. Teaching and Teacher Education, 23(5), 602-611. https://doi.org/10.1016/j. tate.2007.02.003

Trudeau, F., \& Shephard, R. J. (2005). Contribution of School Programmes to Physical Activity Levels and Attitudes in Children and Adults. Sports Medicine, 35(2), 89-105. https://doi.org/10.2165/00007256-200535020-00001

Van Wersch, A., Trew, K., \& Turner, I. (1992). Post-primary school pupil's interest in physical education: age and gender differences. The British Journal of Educational Psychology, 62(1), 56-72. https://doi.org/10.1111/j.2044-8279.1992.tb00999.x

Vilhjalmsson, R., \& Kristjansdottir, G. (2003). Gender differences in physical activity in older children and adolescents: the central role of organized sport. Social Science \& Medicine. 56(2), 363-374. https://doi.org/10.1016/S0277-9536(02)00042-4

Wellard, I. (2017). Men, sport, body performance and the maintenance of 'exclusive masculinity'. Leisure Studies, 21(3-4), 235-247. https://doi.org/10.1080/0261436022000030641

Wilson, T. C. (2992). The Paradox of Social Class and Sports Involvement: The Roles of Cultural and Economic Capital. International Review for the Sociology of Sport, 37(1), 5-16. https://doi.org/10.1177/1012690202037001001

Yaman, M. (2007). The Attitudes of the Physical Education Students towards Internet. The Turkish Online Journal of Educational Technology, 6(4), 79-87.

Yildizer, G., Ozboke, C., Tascioglu, R., \& Yilmaz, I. (2017). Examining attitudes of physical education teacher education program students toward the teaching profession. Montenegrin Journal of Sports Science and Medicine, 6(2), 27-33. https://doi.org/10.26773/ missm.2017.09.004

Zivanovic, N., Pavlović, P., Randjelovic, N., Pirsl, D., \& Zivkovic, D. (2015). Sports, Sports Idols and Idolatry. Journal of Sports Science 3, 309-316. https://doi.org/10.17265/2332$\underline{7839 / 2015.06 .007}$

\section{Bojan Mašanović}

University of Montenegro, Faculty for Sport and Physical Education Narodne omladine bb, 81400 Nikšić, Montenegro bojanma@ucg.ac.me 


\section{Spolne i dobne razlike u stavovima srbijanskih učenika prema nastavi Tjelesne kulture i njihovim preferencijama prema načinu organizacije nastave}

\section{Sažetak}

Ovo istraživanje provedeno je s ciljem ispitivanja spolnih i dobnih razlika u stavovima srbijanskih učenika prema nastavi Tjelesne kulture i njihovim preferencijama prema načinu organizacije nastave. Uzorak od 542 učenika podijeljen je na 4 poduzorka: 140 učenica $(13,51 \pm 0,41)$ i 129 učenika $(13,47 \pm 0,33)$ sedmih razreda osnovnih škola, 134 učenice $(16,49 \pm 0,36)$ i 139 učenika $(16,44 \pm 0,37)$ drugih razreda srednjih škola. Kako bi se postigla svrha istraživanja, ispitanici su dobrovoljno popunili dva standardizirana upitnika. Za određivanje značajnosti razlika u stavovima prema nastavi Tjelesne kulture između učenika različitog uzrasta i različitoga spola koristila se ANOVA, a za ispitivanje značajnosti razlika u preferencijama učenika prema načinu organizacije nastave na satu Tjelesne kulture koristio se hi kvadrat test. Rezultati su pokazali da učenici osnovnih škola imaju značajno pozitivnije stavove prema nastavi Tjelesne kulture u odnosu na učenike srednjih škola i da mlađi učenici pokazuju više preferencija prema nastavi organiziranoj u spolno homogenim grupama, nasuprot starijim učenicima koji se radije opredjeljuju za rad u spolno mješovitim grupama. Zaključak ovog istraživanja jest da se stavovi srbijanskih učenika prema nastavi Tjelesne kulture i njihove preferencije prema načinu organizacije nastave na satu mijenjaju s uzrastom i u odnosu na pripadnost spolu.

Ključne riječi: nastavni sat; osnovne i srednje škole; Srbija.

\section{Uvod}

U posljednje vrijeme sve je veći broj istraživanja koja proučavaju pitanja koja se odnose na stavove učenika prema nastavi i njihove preferencije kada je u pitanju način organizacije nastavnoga sata (Atan i Imamoglu, 2016; Mercier, Donovan, Gibbone i Rozga, 2017; Silverman i Subramaniam, 1999; Trudeau i Shephard, 2005; Yaman, 2007; Yildizer, Ozboke, Tascioglu i Yilmaz, 2017). Naime, istraživači sve više zanimanja pokazuju za pitanja koja se izravno odnose na problem nedovoljno zastupljenog broja 
tjednih nastavnih sati Tjelesne kulture, zatim na kvalitetu nastave, nastavne sadržaje i metode, kao i na opremljenost prostora u kojima se izvod nastava Tjelesne kulture, raznovrsnost rekvizita koji se u nastavi koriste i pitanja koja se odnose na učestalost izbjegavanja nastavne Tjelesne kulture od učenika adolescentskog uzrasta (Babin, Bavčević i Prskalo, 2010; Babin, Bavčević i Vlahović, 2013; Bavčević, 2016; Bavčević, Babin i Prskalo, 2006; Morgan i Hansen, 2008; Olafson, 2002).

Značajan broj dostupnih istraživanja ukazuje na činjenicu da su odlučujući faktori koji utječu na stavove učenika prema Tjelesnoj kulturi i preferencijama prema načinu organizacije nastave Tjelesne kulture, upravo spol i uzrasna dob (Carroll i Yim, 1997; Lyu i Gill, 2011; Shropshire, Subramaniam i Silverman, 2007). Prema tome, velik broj istraživača ispituje stavove dječaka i djevojčica, različite uzrasne dobi, s ciljem ukazivanja na potrebu za osuvremenjivanja nastavnih planova i programa, odnosno osmišljavanja raznovrsnih aktivnosti u okviru postojećih nastavnih programa koji bi zadovoljili potrebe, prije svega djevojčica i dječaka, ali i djece različite uzrasne dobi. Djevojčice i dječaci posjeduju sklonosti prema različitim sportovima (Alm i Brolin Laftman, 2018; Slater i Tiggemann, 2011), pa se djevojčice prije opredjeljuju za sportove koji imaju estetsku komponentu, a dječaci preferiraju sportove u kojima dominiraju tjelesni kontakti i snaga (Wellard, 2017). Djevojčice se više opredjeljuju za sportove koji ne ugrožavaju stereotipe ženskog ponašanja i izgleda, tako da radije biraju odbojku, klizanje ili nešto slično, a dječaci više vole sportove visokoga rizika kao što su, prije svega, borilački sportovi, ragbi, hokej ili slični (Clément-Guillotin, Chalabaev i Fontayne, 2012). Iako je činjenica da postoje značajne razlike kada su u pitanju fiziološke, anatomske, psihološke i socijalno-kulturološke karakteristike među spolovima u pitanju (Greydanaus i Patel, 2002), ipak, gledajući u prošlost, lako je uočljivo da je sport tradicionalno bio područje muškog postignuća. Dječaci su bili uključivani u nastavu Tjelesne kulture, a djevojčice su se u isto vrijeme, ali na drugome mjestu osposobljavale za buduće, dobre domaćice (Coakley, 2015). Međutim, posljednjih desetljeća prošloga, kao i u godinama tekućeg stoljeća, tendencija je da se razlike među spolovima neutraliziraju kada je u pitanju tjelesna aktivnost (Klomsten, Skaalvik i Espnes, 2004). Iako je sport podjednako dostupan, činjenica je da i danas djevojčice sudjeluju u manje sportskih aktivnosti nego dječaci (Schmalz i Kerstetter, 2006), pa to i dalje predstavlja značajan problem kojim se aktivno bavi velik broj istraživača.

Općenito je poznato da u razdoblju adolescencije dolazi do karakterističnih bioloških promjena i značajnih razlika u interesima djevojčica i dječaka za stvari koje ih okružuju. U skladu s tim, kada je u pitanju nastava Tjelesne kulture, zanimljivo je naglasiti da zanimanje djevojčica za nastavu Tjelesne kulture drastično opada (Sarkin, McKenzie i Sallis, 1997), a zaključci značajnog broja istraživanja pokazuju da zainteresiranost dječaka za nastavu Tjelesne kulture ostaje na istoj razini kao i u predadolescentskom razdoblju (Vilhjalmsson i Kristjansdottir, 2003). Na navedene činjenice utječe općenito prihvaćen kulturološki model muškarca koji se ogleda u 
ulozi branitelja i hranitelja obitelji, pa su zbog toga dječaci više okrenuti sportskim aktivnostima, budući da im one mogu predstavljati potencijalni izvor materijalne dobiti i osobne vrijednosti (Ryska, 2003). Ipak, činjenica je da i djevojčice i dječaci pristupaju sportu na različite načine (Alić, 2017), a poticaji za sudjelovanjem u fizičkim aktivnostima također se razlikuju od društvene zajednice do društvene zajednice, a uvjetovani su tradicionalnim stereotipima (Eagly i Wood, 1999) i specifičnostima koje krase pojedine društvene zajednice. Stoga su istraživanja takvog karaktera uvelike uvjetovana društvenim i kulturološkim specifičnostima (Wilson, 2002).

$S$ druge strane, kada je u pitanju razlika u godinama, zanimljivo je istaknuti da motivacija učenika za bavljenje fizičkim aktivnostima u adolescentskoj dobi opada usporedno s odrastanjem (Marttinen, Fredrick i Silverman, 2018). Naime, razlozi za izraženijim negativnim stavovima starijih učenika prema nastavi Tjelesne kulture ogledaju se u raznovrsnijim interesima starije djece koje im nudi suvremeni način života i u sve manjem prostoru koji dobiva tjelesna aktivnost (Mehmeti, 2015). Sve veći je broj npr. „gejmera“ koji predstavljaju dječje idole, a identificiranje sa sportašima sve se manje susreće kod današnjih adolescenata (Sindik, Rendulić, Čorak i Lewis, 2014). Također, značajan faktor koji negativno djeluje jest utjecaj roditelja, koji s odrastanjem dramatično opada pa samim time djeca rade značajan otklon od zdravih stilova života (Cote, 1999; Boisa, Sarrazina, Brustad, Trouilloud i Cury, 2005).

Kada je u pitanju organizacija nastave, u literaturi nailazimo na zaključke koji ukazuju na činjenicu da ne postoje razlike u stavovima učenica i učenika istog uzrasta kada je u pitanju preferencija prema načinu organizacije nastave (Arabaci, 2009). Međutim, činjenica je da postoje razlike između ispitanika različitog uzrasta, koje se ogledaju u tome što učenici osnovnih škola preferiraju organizaciju nastave $\mathrm{u}$ homogenim grupama, $\mathrm{tj}$. $\mathrm{u}$ grupama $\mathrm{u}$ kojima bi djevojčice i dječaci bili fizički razdvojeni (Lyu i Gill, 2011), a učenici srednjih škola preferiraju organizaciju nastave u mješovitim grupama (Koca, Asci i Demirhan, 2005).

Istraživanja spolnih i dobnih razlika kod stavova srbijanskih učenika prema nastavi Tjelesne kulture i njihovih preferencija prema načinu organizacije nastave ograničena su, odnosno ne postoje istraživanja koja bi na adekvatan način odgovorila na istraživačko pitanje koje je proisteklo iz prije pobrojanih činjenica i regionalnih i kulturoloških specifičnosti. Stoga je ovo istraživanje korisno jer može pružiti konkretna znanja koja bi unaprijedila trenutno stanje na terenu u ovoj kulturološki karakterističnoj zemlji. Cilj ovoga istraživanja bio je ispitati stavove srbijanskih učenika prema nastavi Tjelesne kulture i njihovu preferenciju prema načinu organizacije nastave u odnosu na spol i dob.

\section{Metode}

\section{Ispitanici i karakteristike uzorka}

Ovim istraživanjem obuhvaćen je uzorak od 542 učenika osnovnih i srednjih škola iz Bačke Topole i Srbobrana (Sjevernobački i Južnobački okrug Autonomne Pokrajine 
Vojvodine, tj. sjeverni dio Republike Srbije), podijeljenih u 4 poduzorka: 140 učenica (prosječnog uzrasta $=13,51 ; \mathrm{SD}= \pm 0,41$ ) i 129 učenika (prosječnog uzrasta $=13,47$; $\mathrm{SD}= \pm 0,33$ ) sedmog razreda osnovnih škola, 134 učenice (prosječnog uzrasta $=16,49$; $\mathrm{SD}= \pm 0,36)$ i 139 učenika (prosječnog uzrasta $=16,44 ; \mathrm{SD}= \pm 0,37$ ) drugog razreda srednjih škola. Učenici sedmoga razreda osnovne škole i drugoga razreda srednje škole odabrani su zbog razlika u biološkom razvoju, kao i u psihološkoj zrelosti i interesu karakterističnom za uzrasnu dob. Nastava u svim razredima izvođena je u skladu s nastavnim planom i programom Republike Srbije koji predviđa po 2 školska sata tjedno. Sadržaj nastavnoga plana i programa u europskim zemljama i sadržaj nastavnog plana i programa u Republici Srbiji praktički se ne razlikuju, budući da su primarno zastupljene aktivnosti sportske igre, atletika i gimnastika. Kriterij za izbor ispitanika koji će ući u uzorak bio je sljedeći: redovno pohađanje nastave Tjelesne kulture i mjesto stanovanja na području Republike Srbije.

\section{Instrumenti}

Istraživačka tehnika kojom su utvrđeni stavovi učenika prema nastavi Tjelesne kulture i njihove preferencije prema načinu organizacije rada na satima u odnosu na uzrast i spolnu pripadnost bila je anketa u okviru koje su se koristila dva upitnika. Prvi upitnik sastojao se od dva dijela; prvi je dio sadržavao pitanja o mjestu stanovanja, uzrastu, uspjehu u školi i pripadnosti spolu, a u drugom se dijelu tražio odgovor na pitanje oblika organizacije nastave koji učenici preferiraju: nastavu u mješovitim grupama ili nastavu u homogenim grupama (Arabaci, 2009). Drugi upitnik bio je standardni upitnik pod nazivom "Attitude Toward Physical Education Scale“ (Demirhan i Altay, 2001).

\section{Način mjerenja}

Popunjavanje upitnika trajalo je u prosjeku 10 minuta, a ispitanici su dobrovoljno odlučili o sudjelovanju u istraživanju. S obzirom na to da su maloljetni, prije samoga anketiranja zatražena je pisana suglasnost roditelja. Važno je naglasiti da je anketa bila anonimna i da su svi odgovori bili strogo povjerljivi. Ispitanici su, i pored svega navedenoga, bili u mogućnosti u bilo kojem trenutku prekinuti sudjelovanje u anketi, no, od ispitanika to nije učinio. Prikupljanje podataka izvršeno je u njihovim školama, za vrijeme nastave sata razrednika.

\section{Analiza podataka}

Dobiveni podaci analizirani su koristeći se statističkim paketom za društvene znanosti (SPSS za Windowse, verzija 20.0). Za određivanje značajnosti razlika u stavovima prema nastavi Tjelesne kulture među učenicima različitoga uzrasta i različitoga spola koristila se ANOVA, a za ispitivanje značajnosti razlika u preferencijama prema nastavi Tjelesne kulture koristio se Chi-square test. Statistička značajnosti određena je na razini $\mathrm{p}<0,05$. 


\section{Rezultati}

U Tablici 1 prikazani su deskriptivni statistički parametri za stavove učenica i učenika osnovnih i srednjih škola prema nastavi Tjelesne kulture. Analizom Tablice 1 primjećuje se značajna razlika u stavovima prema nastavi Tjelesne kulture između učenica i učenika osnovnih i srednjih škola $(\mathrm{F}=31,419, \mathrm{p}<0,05)$. Pregledom prosječnih vrijednosti rezultata dobivenih s pomoću skale „Attitude Toward Physical Education Scale“, više vrijednosti pronalazimo kod učenica i učenika osnovnih škola $(3,96)$, a niže rezultate pronalazimo kod učenica i učenika srednjih škola $(3,58)$.

Ako analiziramo samo učenike srednjih škola, značajna razlika primjećuje se među polovima $(\mathrm{F}=29,351, \mathrm{p}<0,01)$, $\mathrm{u}$ korist dječaka te dobne skupine $(3,76) \mathrm{u}$ odnosu na djevojčice $(3,42)$. Slična situacija primjećuje se ako gledamo samo rezultate učenika osnovnih škola $(\mathrm{F}=2,211)$. Razlika na osnovi spolne pripadnosti također je značajna $\mathrm{p}<, 05$, a vrijednosti rezultata dobivenih s pomoću ,Attitude Toward Physical Education Scale" kod učenika su ponovno u korist dječaka $(4,00)$ u odnosu na djevojčice $(3,96)$. I na kraju, $\mathrm{u}$ Tablici 1 jasno se vidi da se stavovi prema nastavi Tjelesne kulture mijenjaju u skladu s uzrastom i kod dječaka $(\mathrm{F}=26,252 ; \mathrm{p}<0,05)$ i kod djevojčica $(\mathrm{F}=33,759$; $\mathrm{p}<0,05)$. Više vrijednosti primjećuju se kod učenika osnovnih škola $(4,00)$ u odnosu na učenike srednjih škola $(3,76)$, također, više vrijednosti rezultata na skali procjene vidimo kod učenica osnovnih škola $(3,96)$ u odnosu na učenice srednjih škola $(3,42)$.

Tablica 1

U Tablici 2 prikazani su deskriptivni statistički parametri za preferencije učenika osnovnih i srednjih škola prema načinu organizacije nastave na satima Tjelesne kulture. Preferencije učenika različitog uzrasta značajno se razlikuju $\left(E^{2}=62,649, p<0,05\right)$. Učenici osnovnih škola pokazuju više preferencija prema nastavi organiziranoj u homogenim grupama $(66,54 \%)$, nasuprot većini učenika srednjih škola $(68,86 \%)$ koji pokazuju više preferencija prema nastavi organiziranoj u mješovitim grupama.

Za sklonosti prema načinu organizacije nastave na satima Tjelesne kulture između pripadnika različitih spolova, statistički značajna razlika nije pronađen ni kada su u pitanju učenice, niti učenici osnovnih škola $\left(E^{2}=, 290 ; p>0,05\right)$, ni kada su u pitanju učenice i učenici srednjih škola $\left(E^{2}=1,179, p>0,05\right)$. Većina učenika osnovnih škola pokazuje više sklonosti prema nastavi organiziranoj u homogenim grupama, odnosno za 67,85\% djevojčica i 65,12\% dječaka. Nasuprot njima većina učenika srednjih škola, a među njima $67,16 \%$ djevojčica i 70,50\% dječaka pokazuje više sklonosti prema nastavi organiziranoj u mješovitim grupama.

Ako međusobno usporedimo samo učenice različitoga uzrasta kada je u pitanju preferencija organizacije nastave na satima Tjelesne kulture, vidjet ćemo da značajna razlika postoji $\left(\mathrm{E}^{2}=25,791 ; \mathrm{p}<0,05\right)$, kao i da značajna razlika također postoji i između dječaka različitoga uzrasta $\left(E^{2}=30,697 ; \mathrm{p}<0,05\right)$.

Tablica 2 


\section{Rasprava i zaključak}

Rezultati ovoga istraživanja pokazuju da između različitih dobnih skupina postoje značajne razlike u stavovima prema nastavi Tjelesne kulture. Učenici sedmoga razreda osnovnih škola imaju značajno pozitivnije stavove prema nastavi Tjelesne kulture u odnosu na učenike drugoga razreda srednjih škola. Ti rezultati u skladu su s prethodnim istraživanjima (Atan i Imamoglu, 2016; Silverman i Subramaniam, 1999; Subramaniam i Silverman, 2007) koja također prikazuju pozitivniji odnos učenika nižih razreda prema nastavi Tjelesne kulture u odnosu na učenike viših razreda. Razlog opadanja interesa kod starijih učenika za nastavu Tjelesne kulture jest sazrijevanje koje sa sobom nosi više obaveza, više odgovornosti, ali i nedovoljna demokratičnost u nastavi koja učenicima nudi isključivo tradicionalno zastupljene aktivnosti kao što su sportske igre, atletika i gimnastika (Bjelica i Petković, 2009).

$S$ druge strane, razlika koja se vidi između pripadnika različitih spolova u stavovima prema nastavi Tjelesne kulture, nije iznenađenje. Pozitivniji stavovi kod obje dobne skupine utvrđeni su kod dječaka, što je također u skladu s navodima iz literature (Shropshire i sur., 1997; Subramaniam i Silverman, 2007; Trudeau i Shepard, 2005). Jedan od razloga koji može objasniti negativniji stav kod djevojčica činjenica je da su u nastavnome planu i programu timski sportovi sadržani u većoj mjeri, uz određene elemente atletike i gimnastike. Takav sadržaj nastavnoga programa manje je zanimljiv djevojčicama u odnosu na sportove koji zahtijevaju estetske elemente koji nisu zastupljeni u opsegu koji bi djevojčice preferirale (Koivula, 2001). Djevojčice vole biti prepuštene same sebi, češće se okreću pojedinačnim sportovima (Clément-Guillotin i sur., 2012; Schmalz i Kerstetter, 2006), što im sadašnjim planom i programom nije omogućeno. Nasuprot tome, želja dječaka za samoisticanjem, popularnošću među sebi sličnima i među pripadnicama suprotnoga spola općenito je poznata. Fizička aktivnost im sveobuhvatnim tjelesnim napretkom, a također i uspjesima na školskim sportskim nadmetanjima, pruža mogućnost da se dokažu, ali i identificiraju s uspješnim sportašima ili drugim idolima koje pokušavaju oponašati i slijediti (Zivanovic, Pavlovic, Randjelovic, Pirsl i Zivkovic, 2015).

Ne bi trebalo zaboraviti ni podatak da učenice osnovnih škola imaju pozitivnije stavove prema nastavi Tjelesne kulture od učenica srednjih škola. To je također očekivano i u skladu je s prijašnjim navodima u kojima nalazimo da djevojčice do svoje trinaeste godine imaju ist ili čak veći interes za sportskom aktivnošću u odnosu na dječake, ali se nakon toga razdoblja situacija mijenja (Van Wersch, Trew i Turner, 1992). Važan motiv žena za bavljenjem sportom borba je za ravnopravnošću i želja da pokažu kako nisu nužno slabiji spol (Gromeier, Koester i Schack, 2017). Taj motiv posebno je prisutan u kasnom djetinjstvu i ranoj adolescenciji, kada natjecanja s prijateljima daju poseban motiv iskazivanja vlastite kompetencije (Frederics i Eccles, 2002; Gibbons, Lynn i Stiles, 1997). Međutim, u trenutku kada cjelokupna nastava u školi postaje opsežnija, djevojčice radije zapostavljaju sportske aktivnosti, a usredotočuju se na zadatke koji su tradicionalno vezani uz ženski spol (Coakley, 
2015). Također, sklone su tome da ranije, u odnosu na dječake, usvajaju ponašanja $\mathrm{i}$ interese u formi odraslih, odnosno više ih zabrinjava svakodnevna problematika odraslih (Singh, Dhanda i Shanwal, 2010).

Sljedeće što rezultati ovog istraživanja pokazuju jest da se preferencije prema načinu organizacije nastave Tjelesne kulture značajno mijenjaju tijekom sazrijevanja, pa tako primjećujemo značajne razlike između učenika osnovnih i srednjih škola. Učenici osnovnih škola pokazuju više preferencija prema nastavi organiziranoj u spolno homogenim grupama (66,54\%), za razliku od učenika srednjih škola koji se radije opredjeljuju za rad u spolno mješovitim grupama (68,86\%). Razlog za različitu preferenciju nalazi se u promjeni odnosa prema suprotnom spolu, koja rezultira da u starijem uzrastu djevojčice i dječaci pokazuju bolju međusobnu toleranciju (Arabaci, 2009). Ako te podatke usporedimo s dosadašnjim istraživanjima, pronaći ćemo veliku sličnost s njima, pa tako Koca, Asci i Demirhan (2005) ukazuju na činjenicu da većina učenika viših razreda pokazuje preferencije prema nastavi organiziranoj u spolno mješovitim grupama, a Lyu i Gill (2011) tvrde da učenici nižih razreda pokazuju preferencije prema nastavi organiziranoj u spolno homogenim grupama. Za preferencije prema načinu organizacije rada na satima Tjelesne kulture između pripadnika različitih spolova nije pronađena statistički značajna razlika ni kada su u pitanju učenice i učenici osnovnih i srednjih škola.

Da bi se nastava učinila zanimljivijom učenicima srednjih škola i djevojčicama oba uzrasta koji u srbijanskim školama pokazuju manje interesa za nastavom Tjelesne kulture, potrebno je osuvremeniti postojeće nastavne planove i programe. Neophodno je razbiti krute prepreke i otpore koji sprečavaju pozitivne promjene jer je cilj da u nastavi bude što više aktivne i zadovoljne djece. Zavod za unapredivanja obrazovanja i vaspitanja, odnosno Centar za razvoj programa i udžbenika, koji obavlja stručne poslove koji se odnose na pripremanje programa odgoja i obrazovanja mora, s velikom pažnjom, pratiti rezultate istraživanja koja su vezana uz interese mladeži školskog uzrasta i pripremiti sveobuhvatniji materijal koji bi zadovoljio zahtjeve suvremenog društva. Nastava Tjelesne kulture ne treba biti isključivo prilika za učenje, vježbanje i nadmetanje, već ukras svega treba biti kolegijalnost i čovjekoljublje (Bjelica i Petković, 2009), što je također jedan od zahtjeva koji se mora zadovoljiti. Ovo istraživanje može im pomoći u ostvarivanju tog cilja.

Zbog toga što je testiranje obavljeno u Bačkoj Topoli i Srbobranu, gradovima koji se nalaze u Sjevernobačkom, odnosno Južnobačkom okrugu Autonomne Pokrajine Vojvodine, tj. u sjevernom dijelu Republike Srbije, generalizacija dobivenih rezultata ne odnosi se na cijeli teritorij Srbije, jer bi ugrozila eksternu validnost istraživanja. Autonomna Pokrajina Vojvodina razlikuje se od ostalih područja prije svega zbog multietničke strukture stanovništva, koja podrazumijeva da na tom teritoriju živi više od 25 etničkih zajednica, što može utjecati na specifične stavove učenika prema nastavi Tjelesne kulture i preferencije prema načinu organizacije nastave. Ovaj lokalitet se kulturološki izdvaja jer je više bio izložen utjecaju razvijenijih zapadnih kultura, 
do 1918. godine bio je u sastavu Austro-ugarske, pa ako se još uzme u obzir privreda zasnovana na velikom bogatstvu kvalitetnog obradivog zemljišta koja je stanovništvu pružila drugačiji način života u odnosu na stanovnike ostalih okruga širom Srbije, možemo pretpostaviti, ali ne sa sigurnošću, jer takvih istraživanja na teritoriju cijele Srbije nema, da bi kompletna slika bila drugačija, pa je neophodno proširiti istraživanje i na druge regije, kako bi se provjerile potencijalne razlike. U skladu s tim, sljedeća istraživanja trebalo bi organizirati na većem uzorku koji bi obuhvatio učenike iz svih krajeva Srbije, odnosno učenike iz svih 29 upravnih okruga. Na taj bi se način isključile različitosti u stavovima i preferencijama do kojih bi moglo doći zbog etničkih, religijskih, materijalnih i jezičnih različitosti naroda koji složno žive na teritoriju Srbije. Takav pristup sigurno bi uvelike doprinio kvaliteti dobivenih rezultata, ali ne bi umanjio doprinos ove preliminarne studije. Na taj bi način omogućio reprezentativnije podatke na osnovi kojih bi se poduzeli konkretni koraci u modifikaciji postojećih nastavnih planova i programa. 